\title{
PULMONARY FIBROSIS IN WORKERS EXPOSED TO FINELY POWDERED ALUMINIUM
}

\author{
BY \\ JOHN MITCHELL, G. B. MANNING, M. MOLYNEUX, and RONALD E. LANE \\ From the Nuffield Department of Occupational Health, Manchester University, and The Royal Infirmary, Bolton
}

(RECEIVED FOR PUBLICATION SEPTEMBER 29, 1960)

Of 30 workmen at risk 27 were examined and six found to have evidence of pulmonary fibrosis. In the two fatal cases the evidence for pulmonary fibrosis was conclusive and in three other cases it was sufficient; in one case it was suggestive. The clinical, radiological, and pathological features of these six cases are recorded. Results of respiratory function tests on the four non-fatal cases are given. The manufacturing process is described. An analysis of the powder is given, also the results of dust measurement in the contaminated atmosphere. The literature is reviewed and our own experience compared with reports from Germany and Canada. We concluded that the pulmonary fibrosis was caused by the dust inhaled at work and that the component responsible was finely divided aluminium.

Pulmonary fibrosis in an aluminium worker in Great Britain was first reported by Mitchell (1959). A footnote to that paper said that the man who replaced this workman had died of the same disease and that two ambulant cases had been found. The factory made a very fine aluminium powder for fireworks known as "pyro" and a coarser powder for aluminium paint. We have examined 27 of the 30 workers known to have been at risk and now know of six cases. In the two fatal cases the evidence for pulmonary fibrosis was conclusive and in three other cases it was sufficient. In the sixth case there were minimal radiological changes and in view of the occupational history we presumed that we were dealing with a limited form of the same disease. Reviewing our material it seemed highly probable that the dust inhaled caused the pulmonary fibrosis. The increasing use of aluminium and its products in industry and its use as a prophylactic against silicosis called for a more detailed account of this experience.

\section{Case Reports}

Case 1.-A.G. died at the age of 22. After leaving school he worked as an agricultural labourer until he was 19 when he joined the factory in March, 1951 and worked in an atmosphere heavily contaminated with the "pyro" powder until disabled by breathlessness in December, 1953. This breathlessness, which was first noted in September, 1953 was the dominant symptom and progressed relentlessly until death eight months after he stopped work. By March, 1954 he had to walk slowly on the flat, though he was able to sleep comfortably with one pillow. Three months later the breathlessness was such that he spent most of the day in his bedroom; bouts of morning cough, producing occasional scanty mucoid sputum, were very distressing. On the night of August 29 his condition worsened and the following morning he was admitted to hospital desperately ill, pale, sweating, and cyanosed, in a stuporose state, feebly gasping for breath. His temperature was $100 \cdot 4^{\circ} \mathrm{F}$; pulse 110 per minute; respirations 45 per minute; blood pressure was $95 / 70 \mathrm{~mm}$. $\mathbf{H g}$. He died four hours later. Five months before he died he was admitted to hospital for investigation and was found to be a slightly built, young man of healthy appearance. There was no history of previous illness except in November, 1951, when he spent 10 days in hospital with second degree burns of the skin after an explosion at work. Respiratory excursion was poor and medium crepitations were heard mainly over the pectoral and sub-pectoral regions. A pulmonary diastolic impulse was palpable and a systolic thrust was felt over the lower end of the sternum. The chest radiograph (April, 1954) showed appearances of pulmonary fibrosis (Fig. 1). For the nine months he was observed the serial films showed no significant change. The barium swallow was normal, except that the oesophagus was a little displaced to the right in the superior mediastinum. A miniature film (Fig. 2) taken on June 16, 1952 a year after he started the job was correctly passed as normal.

At necropsy the body was wasted; all the organs appeared normal with the exception of the heart and lungs. Both lungs were lightly adherent to the chest wall and there were a few small areas of fibrinous exudate particularly between the lobes. Both lungs were shrunken apparently due to generalized fibrosis, this fibrosis being 


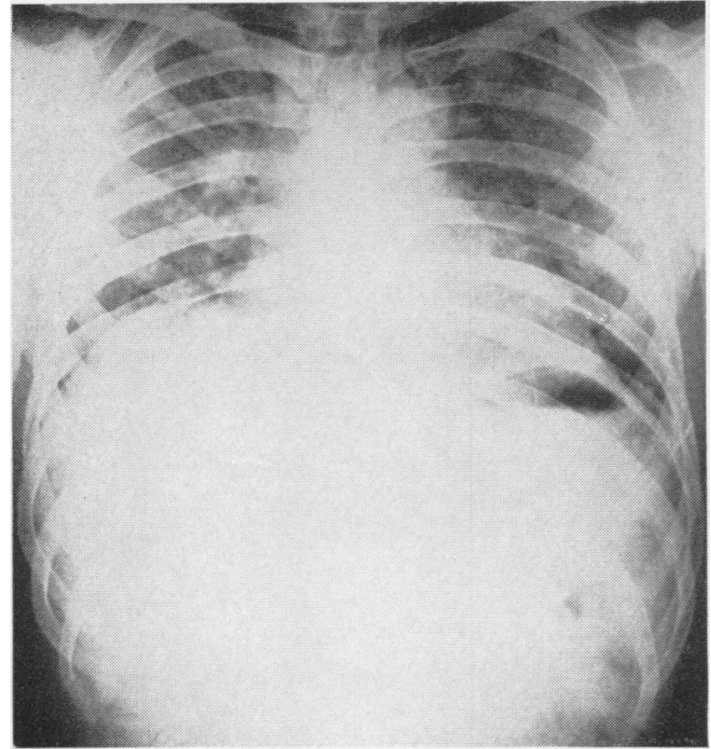

Fig. 1.

Fig. 1.-Case 1, chest radiograph in full inspiration taken on April 9 1954. Raised diaphragm (on screening respiratory excursion was greatly reduced); mediastinum drawn out; abnormal opacities mainly in the upper and mid zones; trachea kinked to the right.

Fig. 2.-Case 1, normal mass miniature radiography film of June 18, 1952.

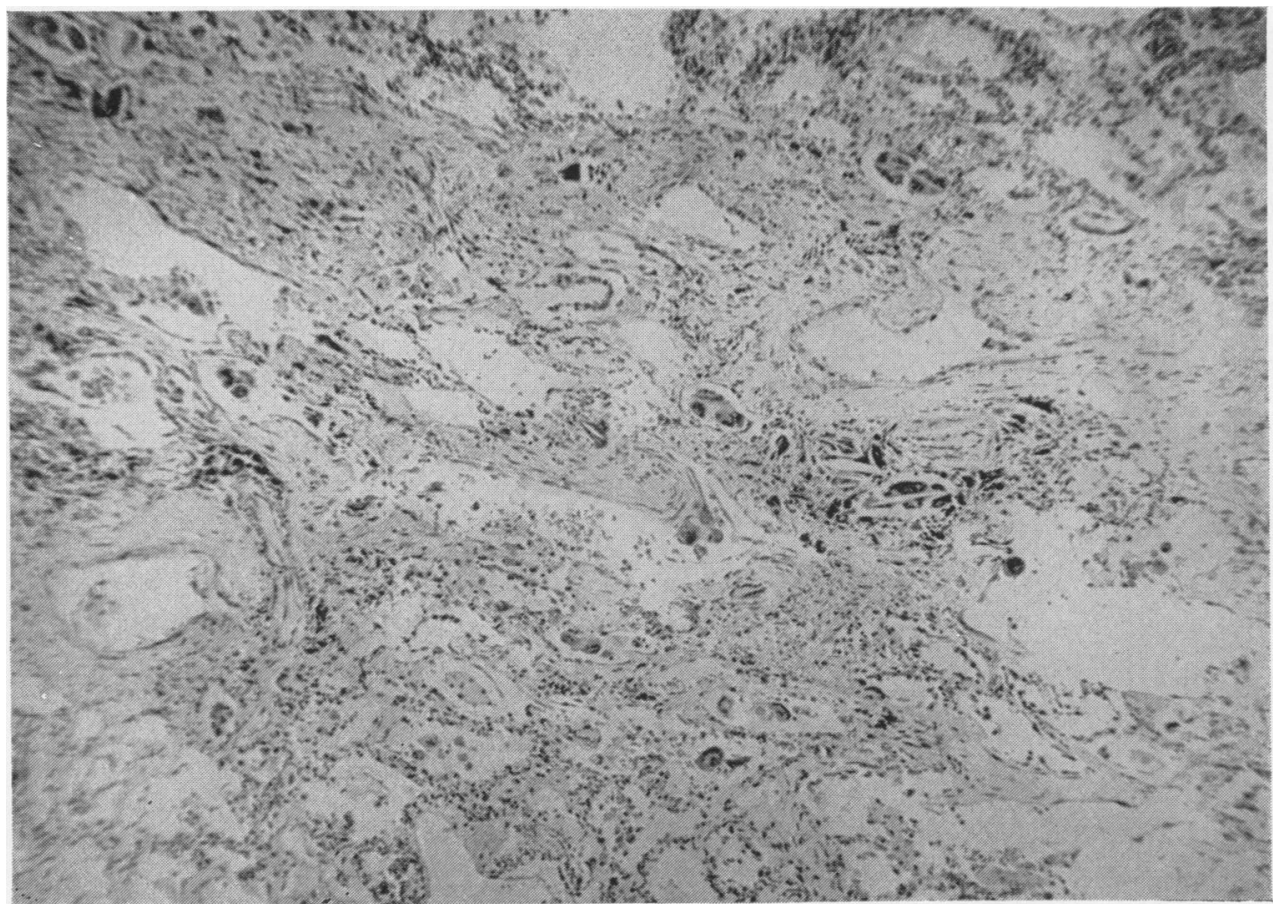

FIG. 3.-Case 1, low power (Haematoxylin and Eosin) showing pulmonary fibrosis, macrophages, and crystal clefts. 


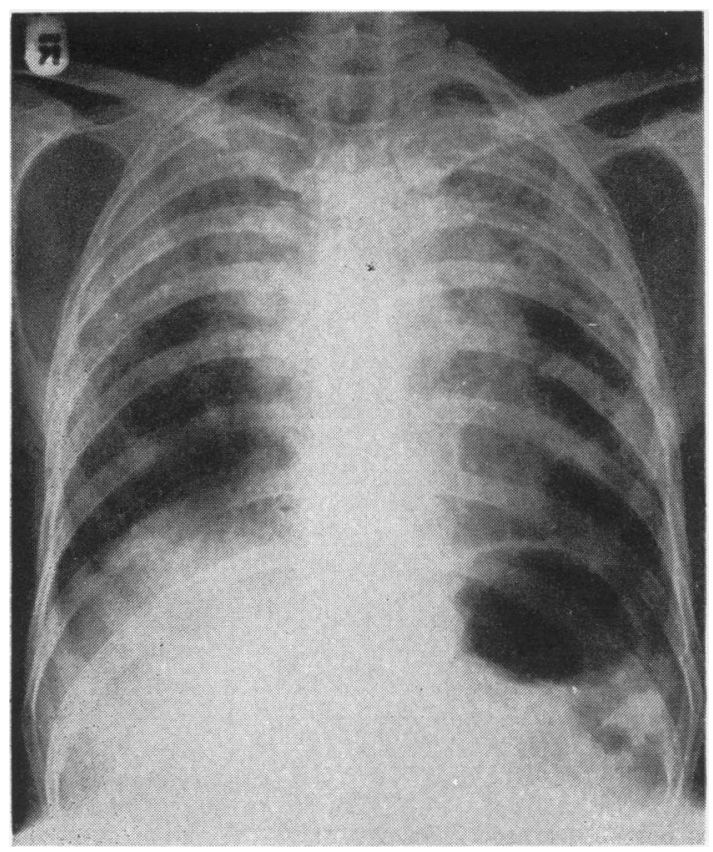

Fig. 4.-Case 2, film taken December 12, 1958, showing gross opacities mainly in the upper and middle zones. The whole mediastinum is pulled up and the trachea kinked to the right. On screening the excursion of the diaphragm was seen to be reduced to less than one inch.

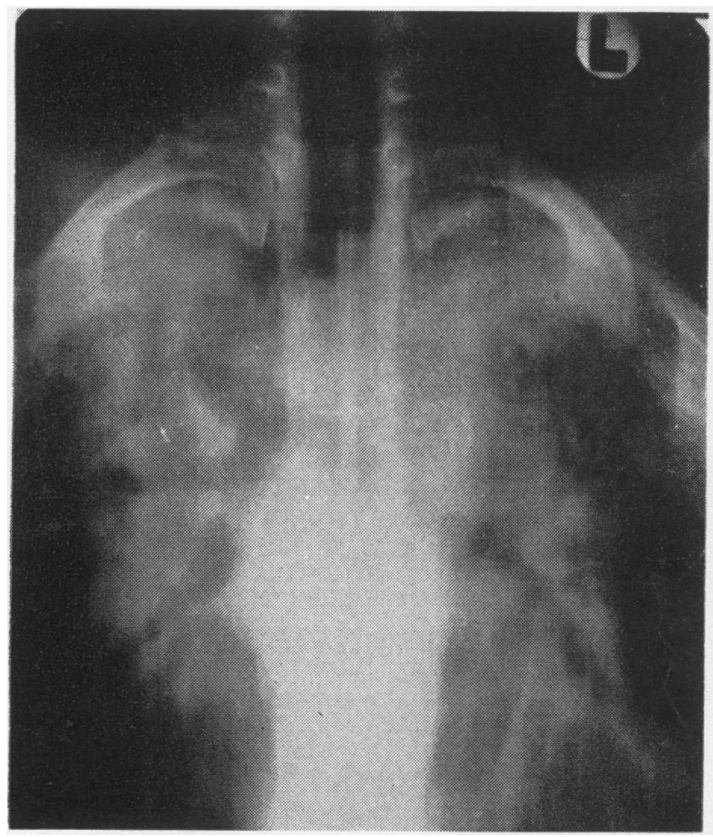

FIG. 5.-Case 2, tomogram of January 28, 1959, showing the gross displacement of the trachea to the right.

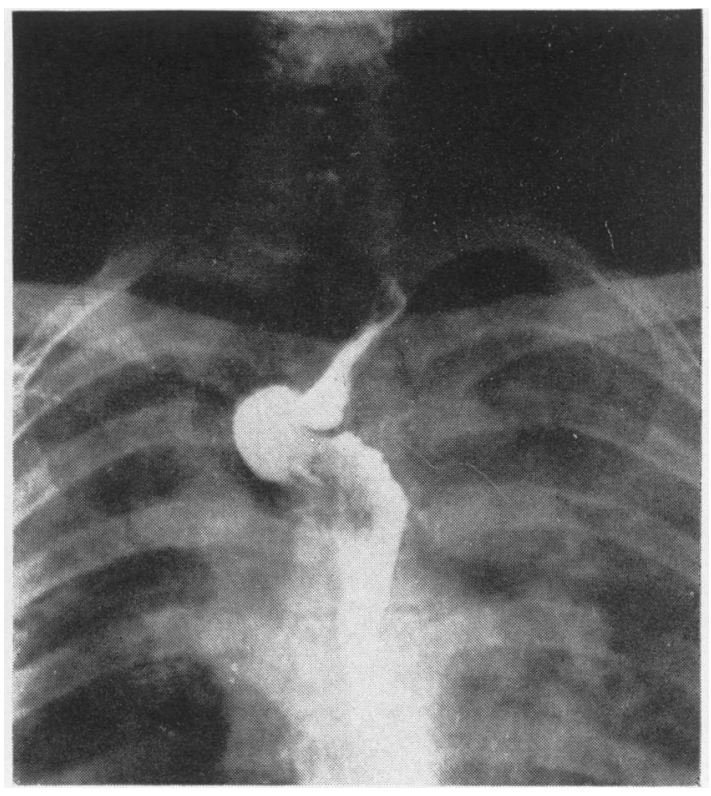

Fig. 6.-Case 2, the barium swallow shows that the oesophagus is also sharply displaced to the right.

most marked in the upper lobes. The heart weighed $16 \mathrm{oz}$. and the right ventricle was dilated and hypertrophied. Microscopical examination of the lungs showed a generalized diffuse fibrosis, non-nodular in character and much of it acellular (Fig. 3). The fibrosis showed varying grades of severity in different areas. Areas of dense fibrosis were present up to $0.5 \mathrm{~cm}$. in diameter and from many of these centres strands of fibrous tissue radiated. The pleura and the connective tissue in the septa were thickened. The moderate number of macrophages present contained pigment and a few very small particles which stained for lipoid but there was no lipoid pneumonia. There were a few giant cells with crystal clefts. Specific staining for aluminium with aurine showed numerous pink particles, apparently aluminium. There was no inflammatory infiltration. There was an occasional area of mild emphysema. There was no obvious endarteritis. Chemical analysis for aluminium showed 227 p.p.m. in the wet lung at the root, 15 p.p.m. at the apex, and a trace at the base. There was no evidence of sarcoidosis, tuberculosis, or other specific disease. Except for the absence of gross emphysema the appearances were similar to those described by Shaver and Riddell (1947) and Goralewski (1950).

Case 2.-E.B. died on February 10, 1959 at the age of 53. Apart from four years war service with the Royal Air Force he had spent all his working life out of doors mainly as a driver in the fish trade, until he joined the factory in May, 1954. He occupied the very job vacated by Case 1 until December, 1957 when breathlessness, which had begun seven months earlier, compelled him to stop. During the previous 18 months he had lost nearly two stones in weight. There were no other symptoms. 
When examined on December 19, 1957, he looked pale, thin, and ill. His chest expansion was poor. Medium crepitations were heard over the pectoral and subpectoral regions. Blood pressure was $120 / 80 \mathrm{~mm}$. $\mathrm{Hg}$, pulse 80 per minute, regular. The chest radiographs were grossly abnormal (Figs. 4, 5, and 6). He said that a chest radiograph taken in 1942, before war service, was normal. By October, 1958, he was very slow on the flat and had to rest several times on the stairs. He had a hoarse voice and immobile left vocal cord (no cause other than pulmonary fibrosis and kinking of the trachea was ever found for this). He had lost nearly a stone in weight since his previous attendance. Pulse 110 per minute, regular. A diastolic impulse over the pulmonary area was palpable. Blood pressure was $100 / 70 \mathrm{~mm}$. $\mathrm{Hg}$. On December 12, he reported that his breathlessness was worse. On the morning of February 10, 1959 his general condition began to deteriorate and he was admitted to hospital in a weak state, pale, sweating, cyanosed, and breathing rapidly and feebly. He died about 12 hours later.

At necropsy all the organs appeared normal except the lungs which were densely adherent to the chest wall and the diaphragm, the adhesions being particularly strong at the apices. The lungs (weight $76 \mathrm{oz}$.) showed welldeveloped rib markings, marked pleural thickening, and well-developed bronchopneumonia in both lower lobes. There was bullous emphysema of the left upper lobe and right lower lobe and generalized emphysema of the left upper lobe and the whole of the right lung. Carbon pigment was particularly heavy in both upper lobes. The heart (weight $12 \mathrm{oz}$.) appeared normal in size. There was minimal atheroma in the arteries and a mural clot was attached to the wall of both ventricles. Microscopical examination of the lungs showed a diffuse fibrosis similar in type to Case 1 but apparently not quite so severe and with fewer acellular areas (Fig. 7). There was no evidence of tuberculosis or sarcoidosis in the lungs and no endarteritis. The appearances in this case were similar to those described by Shaver and Riddell (1947) and Goralewski (1950). Specific staining for aluminium with aurine showed only scanty particles of aluminium. Numerous macrophages were present, a few of which contained minute granules which stained for lipoid and others crystal clefts. Chemical analysis for aluminium showed 12.0 p.p.m. in the wet lung at the root, 15.75 p.p.m. at the apex, and 8.5 p.p.m. at the base.

Case 3.-A.R., born on July 5, 1914, left school at 15 and worked in a cotton mill until he was 22 . For the next five years he worked in the moulding shop of a locomotive works until he was called up for military service from 1941 to 1946 . After the war he worked as a labourer not unduly exposed to any dust, except for the one year March, 1953 to March, 1954 when he worked

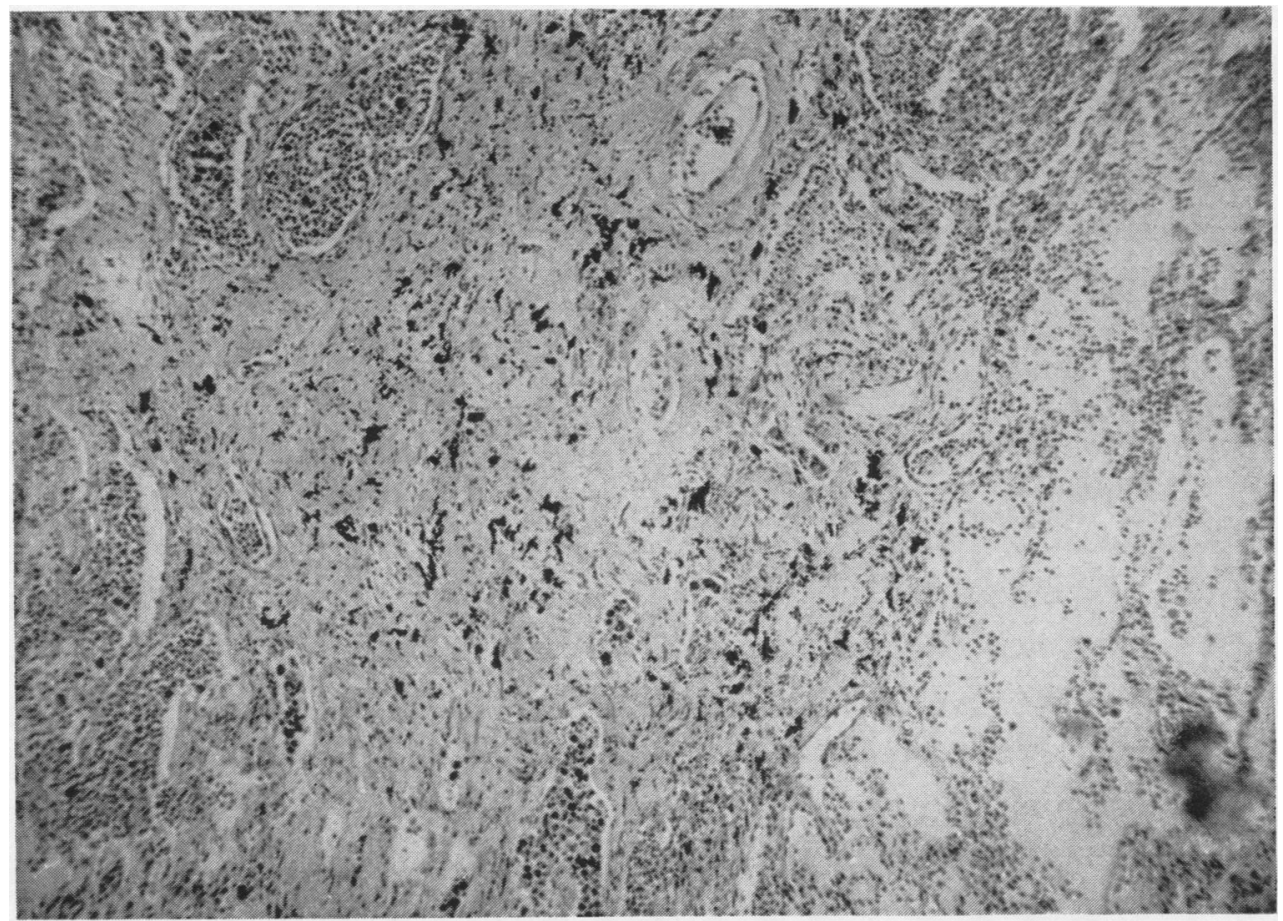

FIG. 7.-Case 2, low power (Haematoxylin and Eosin) showing pulmonary fibrosis, bronchopneumonia, and pigment. 


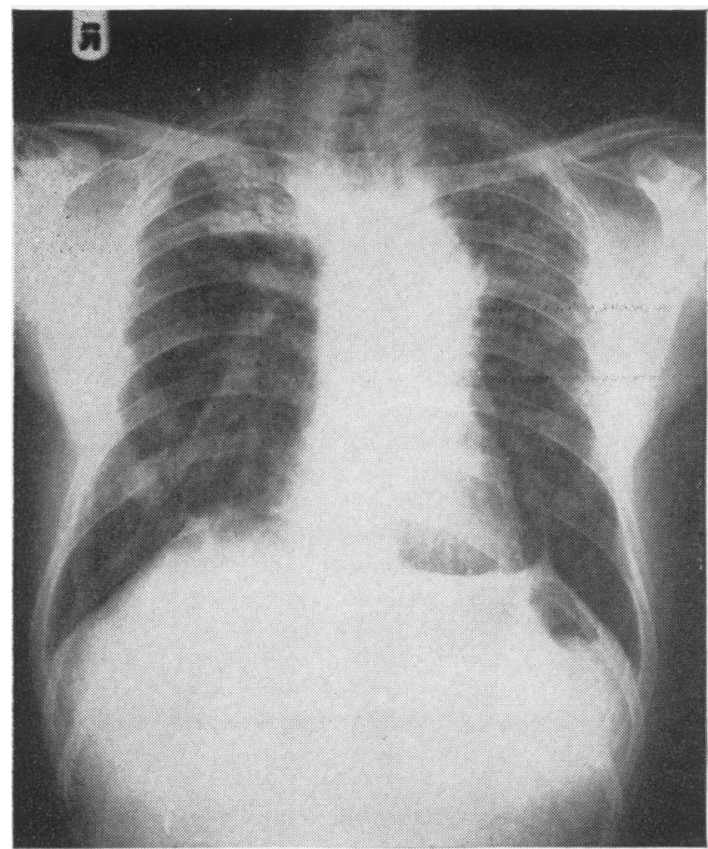

Fig. 8.-Case 3, film of December 23, 1958. Abnormal opacities mainly in the upper zones, the mediastinum drawn upwards and outwards.

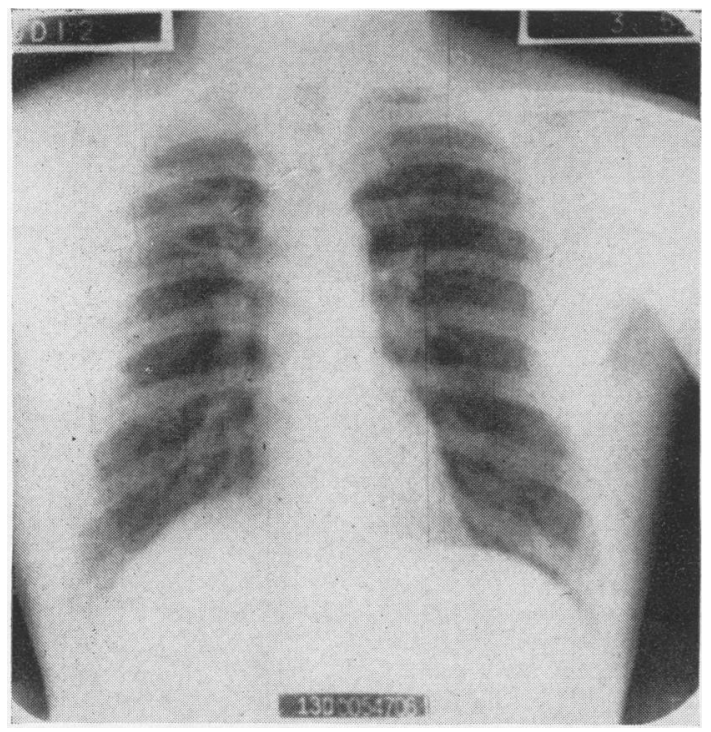

FIG. 9.-Case 3, normal mass miniature radiography film taken on March 5, 1952.

in the factory "polishing" the aluminium powder and then packing it. He had little or no contact with the "pyro" powder. He was under investigation as a

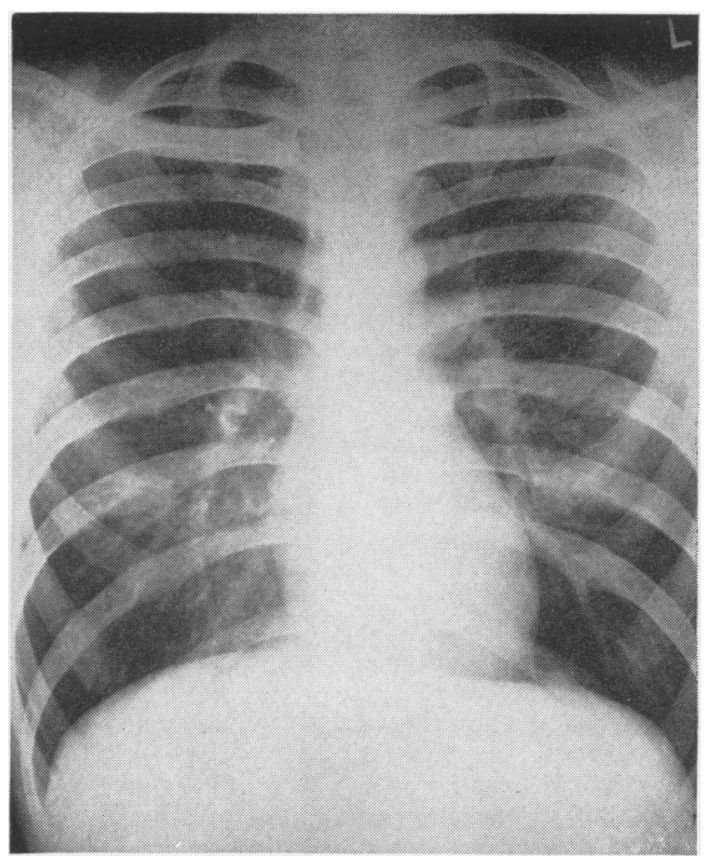

Fig. 10.-Case 4, normal film taken February 11, 1954.

suspected case of pulmonary tuberculosis when first seen by one of us (J.M.) on December 23, 1958. The radiographic appearances (Fig. 8) were thought to be very suggestive of aluminium fibrosis and it was then learned that he had spent a year at the same factory having left four years previously. He had no symptoms and looked well. Rhonchi were heard over both pectoral regions, more so on the right side, and the trachea was deviated to the right. The pulmonary second sound was increased. A miniature film (Fig. 9), taken a year before he started work with aluminium powder was normal.

Case 4.-A.B., born February 3, 1921 was first examined by one of us (J.M.) on February 2, 1959 as a result of the search for ex-workers who had been exposed to the "pyro" dust. He complained of a cough, especially troublesome on change of atmosphere, with scanty mucoid sputum, a choked-up feeling in the chest, and occasional wheezing. He thought he was a little more breathless than he should be on exertion but this latter symptom was only occasionally present and his symptoms were judged to be due to bronchitis. He left school at the age of 14 and was employed in a number of unskilled occupations. From 1950 he worked for four years with aluminium powder, two and a half years of which he worked with the "pyro" powder. Apart from three months working underground in a coal-mine there was no other history of exposure to dangerous dust. A chest radiograph was taken a month before he left the factory. This first film (Fig. 10) dated February, 1954 was normal. Another film (Fig. 11) taken about two 


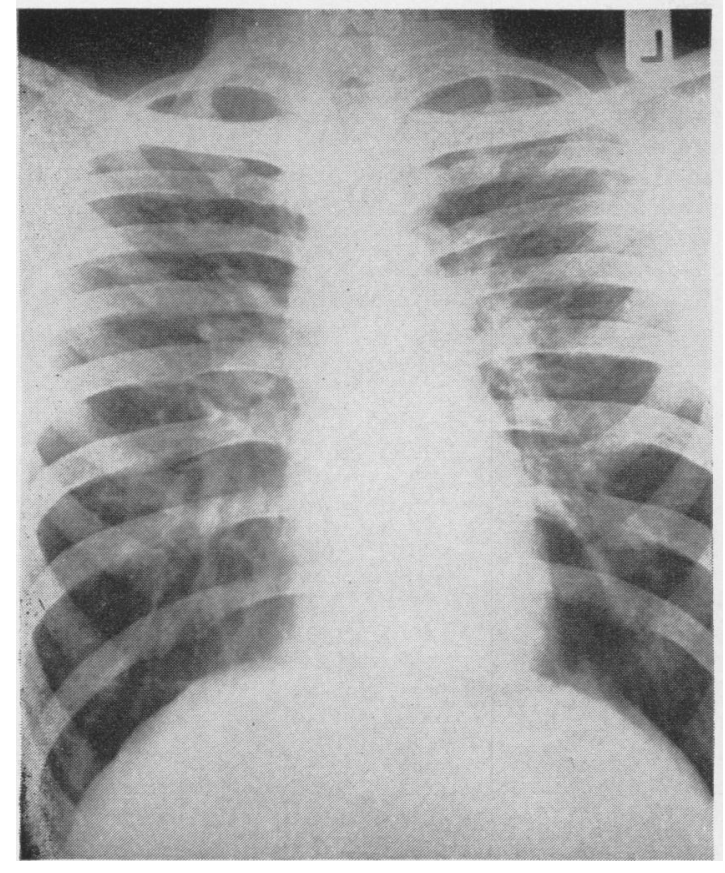

Fig. 11.-Case 4, film taken May 3, 1956 showing abnormal opacities mainly in the upper and middle zones, mediastinum pulled upwards and outwards, tension on the diaphragm indicated by peaking on the left side.

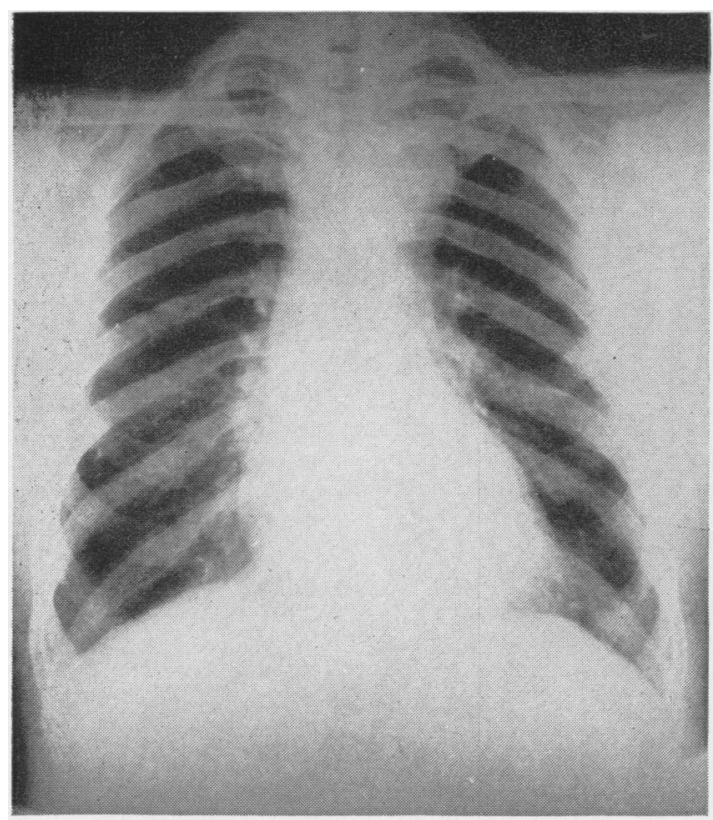

Fig. 12.-Case 5, normal film taken May 15, 1954 showing the rather high aortic arch which was thought to be due to unfolding of the aorta in an elderly subject.

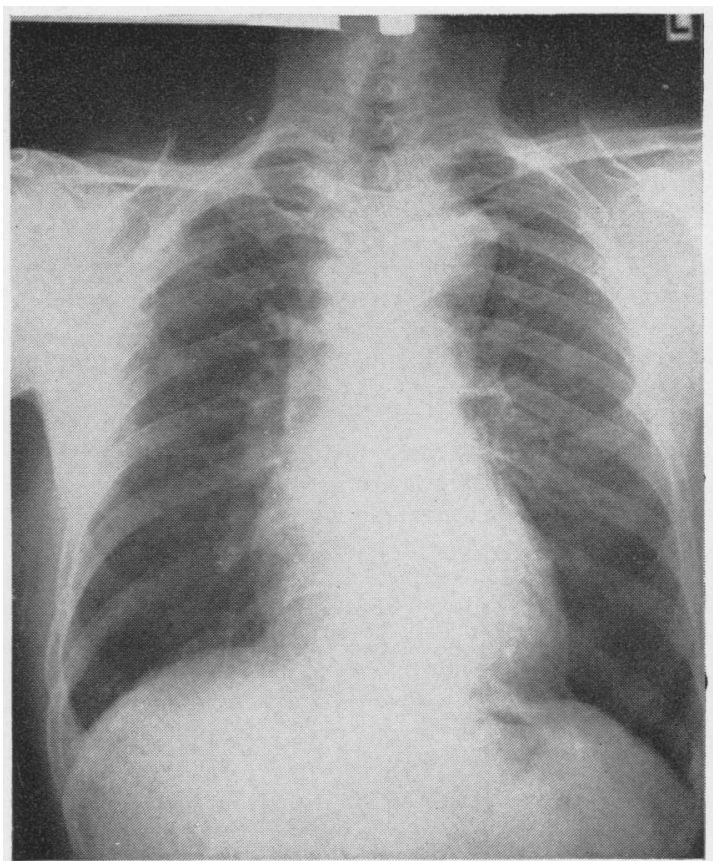

Fig. 13.-Case 5, film taken March 31, 1959. Abnormal opacities have appeared in the upper zones and there is a suggestion that the mediastinum has been pulled upwards and outwards.

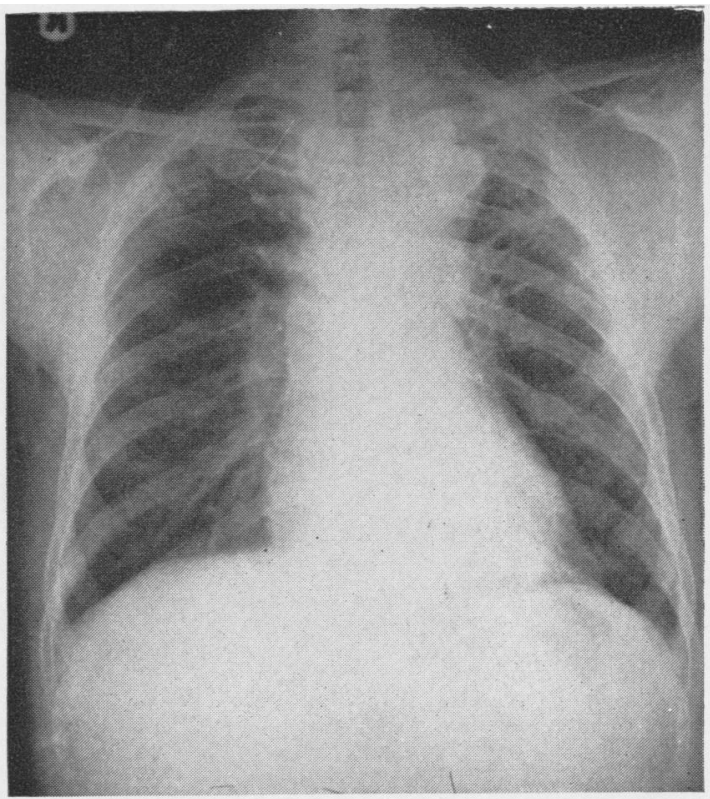

FIG. 14.-Case 5, film taken September 14, 1959 . Following an attack of left upper lobe pneumonia the opacities on the left side became more marked. The greater part of the shadow due to pneumonia has resolved but a certain increased density has persisted. 
years later was abnormal. He was a man of spare build who was troubled with eczema. Apart from reddening of the visible turbinals and posterior pharyngeal wall there were no abnormal physical signs. At the time he came to our notice, he had been attending a Chest Clinic for three years as a case of suspected tuberculosis.

Case 5.-N.J.L. was born on July 20, 1895. After Case 1 was diagnosed this man attended as a fellow worker in May, 1954, for medical examination and chest radiograph (Fig. 12) and nothing abnormal was found. He was re-examined on March 11, 1959, when the clinical examination was again negative but the radiograph (Fig. 13) was abnormal. On April 4, he was admitted to hospital with lobar pneumonia of the left upper lobe. This was treated conventionally and there was nothing remarkable about the course of the illness, except that the increased abnormal opacity on the left side never reverted completely to its former size (Fig. 14). A period of radiological surveillance which, at the time of writing, has lasted for 12 months, has failed to show any further change, and it was concluded that this partial failure of resolution was comparable with that which is sometimes seen in other forms of pneumoconiosis. Since this attack of pneumonia he has complained of increasing breathlessness on exertion and tiredness after work. For nine years he worked polishing and screening the coarser powder and spent only three months handling "pyro" powder. He was last seen in May, 1960 when he was still breathless but was able to do light work away from the powder.

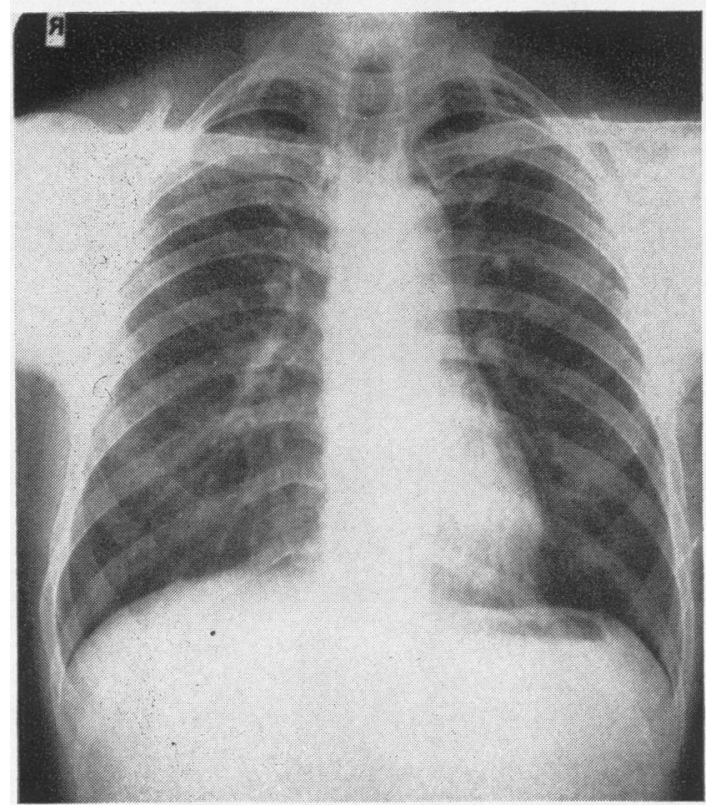

FIG. 15.-Case 6, film taken July 20, 1959. The abnormal opacities are slight and are best seen in the right first space. Subsequent films have failed to show any change.
Case 6.-J.C. was born on June 17, 1908. In June, 1959 a further list of names and addresses was obtained from the management and this man was among those who attended. He was examined and a chest radiograph was taken (Fig. 15) on July 20, 1959, when there were no symptoms nor significant abnormal physical signs. He had worked in the factory polishing and packing for three years from 1952 to 1955 , always in the same room, and always with aluminium powder. He left school in 1925 and worked at a number of skilled and semi-skilled jobs but apart from his work with aluminium there was no employment in dusty occupations.

\section{Tests}

It was notable that no case showed clubbing of the fingers. The conventional laboratory tests were carried out on the first five cases. They all had negative Wassermann and Kahn reactions and the plasma albumin and total globulin were normal. In Cases 3, 4, 5, and 6 the serum protein electrophoretic pattern was normal, and the total and differential white cell counts were normal. Mantoux tests were negative in Cases 1 and 2 and positive $(1 / 100)$ in Cases 3 and 5; they were not carried out in Cases 4 and 6. The erythrocyte sedimentation rate was normal in all except Case 5 where it was slightly raised. Skin contact tests were done using the "pyro" powder in Cases 1 to 5 and a $1 \%$ solution of aluminium nitrate and $1 \%$ aluminium sulphate on Cases 3 to 6 with negative results. In all cases the sputum was repeatedly examined for acid-fast bacilli with negative results; Case 2 had three fasting gastric juices cultured for tubercle bacilli, with negative results.

Respiratory function tests were carried out on Cases 3, 4,5 , and 6 by Dr. Colin Ogilvie, to whom we are grateful for Tables 1 and 2 and the interpretation of the results. The lung volume, ventilatory function of the lung, and diffusing capacity were measured.

In one patient (Case 6), the tests were entirely normal, in two (Cases 3 and 4) there was a moderate impairment of function, and in a fourth (Case 5) the defect was more severe. In all patients, the residual volume, ratio of residual volume to total lung capacity, and the forced expiratory volume as percentage of vital capacity showed relatively little abnormality. Furthermore, the reduction in maximum inspiratory flow rate was at least as great as the reduction in the maximum expiratory rate. These findings suggest that there was no important degree of airway obstruction nor emphysema. The reduced lung volumes indicate pulmonary fibrosis but the fact that the diffusing capacity was only reduced in proportion to the mechanical defect suggests that there was not the diffuse involvement of alveolar and capillary tissues that is found in asbestosis. The findings in two patients with asbestosis (Table 2) are shown for comparison where it will be noted that the ventilatory defect was of the same degree but the diffusion block was considerably greater.

\section{Examination of Exposed Population}

When the first case was seen all fellow workers having any comparable exposure were examined, 
TABLE 1

RESPIRATORY FUNCTION TESTS

\begin{tabular}{|c|c|c|c|c|c|c|c|c|c|c|c|c|}
\hline Case & $\begin{array}{c}\text { Age } \\
\text { (yrs) }\end{array}$ & $\begin{array}{l}\text { Height } \\
\text { (in.) }\end{array}$ & $\begin{array}{l}\text { Weight } \\
\text { (lb.) }\end{array}$ & $\begin{array}{c}\text { Vital } \\
\text { Capacity } \\
\text { (ml.) }\end{array}$ & $\begin{array}{c}\text { Residual } \\
\text { Volume } \\
\text { (ml.) }\end{array}$ & $\begin{array}{c}\text { Total } \\
\text { Lung } \\
\text { Capacity } \\
\text { (ml.) }\end{array}$ & $\begin{array}{c}\text { RV TLC } \\
\text { Ratio } \\
(\%)\end{array}$ & $\begin{array}{l}\text { Maximum } \\
\text { Breathing } \\
\text { Capacity } \\
\text { (1./min.) }\end{array}$ & $\begin{array}{c}\text { Forced } \\
\text { Expiratory } \\
\text { Volume } \\
(\%)\end{array}$ & $\begin{array}{c}\text { Maximum } \\
\text { Inspiratory } \\
\text { Flow Rate } \\
\text { (1./min.) }\end{array}$ & $\begin{array}{c}\text { Maximum } \\
\text { Expiratory } \\
\text { Flow Rate } \\
\text { (1./min.) }\end{array}$ & $\begin{array}{c}\text { Diffusing } \\
\text { Capacity } \\
\substack{\text { (ml./mm. } \\
\text { min.) }}\end{array}$ \\
\hline $\begin{array}{l}3 \\
4 \\
5 \\
6\end{array}$ & $\begin{array}{l}46 \\
39 \\
65 \\
52\end{array}$ & $\begin{array}{l}67 \\
67 \\
66 \\
69\end{array}$ & $\begin{array}{l}136 \\
127 \\
164 \\
133\end{array}$ & $\begin{array}{l}2,460(64) \\
3,330(84) \\
2,280(62) \\
3,840(100)\end{array}$ & $\begin{array}{l}2,040(120) \\
1,250(71) \\
1,440(88) \\
1,960(116)\end{array}$ & $\begin{array}{l}4,500(82) \\
4,580(80) \\
3,720(70), \\
5,800(105)\end{array}$ & $\begin{array}{l}45 \\
27 \\
39 \\
34\end{array}$ & $\begin{array}{c}91(85) \\
76(70) \\
48(43) \\
160(157)\end{array}$ & $\begin{array}{l}76 \\
61 \\
63 \\
77\end{array}$ & $\begin{array}{r}200 \\
300 \\
67 \\
300\end{array}$ & $\begin{array}{l}200 \\
200 \\
120 \\
400\end{array}$ & $\begin{array}{l}22.2(87) \\
21.3(88) \\
14.8(53) \\
25.8(99)\end{array}$ \\
\hline$\overline{\text { Mean }}$ & & & & 2,977 (77) & $1,672(99)$ & 4,650 (89) & $\begin{array}{c}36 \\
\text { (normal } \\
<40 \% \text { ) }\end{array}$ & 94 (89) & $\begin{array}{c}69 \\
\text { (normal } \\
<70 \% \text { ) }\end{array}$ & $\begin{array}{c}217 \\
(\text { normal } \\
>300)\end{array}$ & $\begin{array}{c}230 \\
(\text { normal } \\
>300)\end{array}$ & $21.0(82)$ \\
\hline
\end{tabular}

Percentages of predicted normal are given in brackets.

TABLE 2

ALUMINIUM LUNG DISEASE AND ASBESTOSIS COMPARED. FIGURES ARE \% OF PREDICTED NORMAL (EXCEPT WHERE INDICATED)

\begin{tabular}{|c|c|c|c|c|c|c|c|}
\hline Diagnosis & $\underset{(\%)}{\text { Vital }}$ & 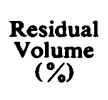 & $\begin{array}{c}\text { Total } \\
\text { Lung } \\
\text { Capacity } \\
(\%)\end{array}$ & $\underset{\substack{\text { Ratio } \\
(\%)}}{\text { RV TLC }}$ & $\begin{array}{l}\text { Max. } \\
\text { Breathing } \\
\text { Capacity } \\
(\%)\end{array}$ & $\begin{array}{l}\text { Forced } \\
\text { Expiratory } \\
\text { Volume \% }\end{array}$ & $\begin{array}{c}\text { Diffusing } \\
\text { Capacity } \\
\text { (ml./mm. Hg/min.) }\end{array}$ \\
\hline $\begin{array}{l}\text { Aluminium fibrosis (four cases) } \\
\text { Asbestosis (two cases) }\end{array}$ & $\begin{array}{l}77 \\
72\end{array}$ & $\begin{array}{l}99 \\
92\end{array}$ & $\begin{array}{l}89 \\
78\end{array}$ & $\begin{array}{c}36 \\
36 \\
\text { (normal } \\
<40 \% \text { ) }\end{array}$ & $\begin{array}{l}89 \\
90\end{array}$ & $\begin{array}{c}69 \\
66 \\
\text { (normal } \\
<70 \% \text { ) }\end{array}$ & $82 \%$ \\
\hline
\end{tabular}

Aluminium lung disease and asbestosis compared. In both conditions, there is a reduction in vital capacity without significant airway obstruction. In asbestosis there is in addition a diffusion barrier.

clinically and radiologically, with negative results. Four years later the second case presented and then a search was made for all the men who had ever worked on the process for six months or more. Altogether there were 30 such men; 27 were examined, two refused examination, and one had emigrated. Details are given in Table 3.

\section{Environmental Study}

The Process.-Aluminium powders fall into two main types: flake varieties made by stamping the cold metal, and granulated varieties made from molten aluminium. The granulated types, in the main, have larger particles which may be spherical in form, whereas the flake powders are, for the most part, flattened; they have a peculiar "leafing" characteristic and for this reason are widely used in aluminium paints. A specially fine type of "flake" powder, known as "pyro", is composed of very small three-dimensional particles. The Germans used this type of powder to mix with explosives in the second World War and in this country it is used in the manufacture of fireworks. This study is concerned only with aluminium powders of the flake variety and particularly with the pyro type.

The patients all worked in a small factory which produced aluminium powder as a side-line; there were never more than 12 men engaged at one time.
The process consisted of treating aluminium foil and stamping it to a coarse powder. From this material both paint and "pyro" powder were made by further stamping which required the addition of grease to prevent the agglomeration of particles. In the manufacture of the paint powder comparatively large quantities of stearin were used; whereas in the manufacture of "pyro" powder the quantity of stearin was kept as low as possible and in 1952 this was largely replaced by mineral oil. Towards the end of the "pyro" process a small quantity of carbon black was added. The stamping of the pyro powder lasted for some 12 hours, which was more than double the time necessary to produce the paint powder. The result was a particularly fine blackish powder. Exposure to high concentrations of dust took place whilst charging and emptying the machines, and during certain weighing and screening processes. Recently men were provided with airline or microfilter respirators but before 1959 no deliberate steps had been taken to prevent the inhalation of dust. The fire and explosion hazard had made the use of exhaust ventilation difficult.

Gravimetric samples of airborne dust were taken with a Hexhlet dust sampler (Wright, 1954). In this very small factory conditions varied considerably from day to day and there were differences between individual workmen depending on the care they took 
TABLE 3

SUMMARY OF FINDINGS AMONG 27 MEN EXPOSED TO FINELY POWDERED ALUMINIUM

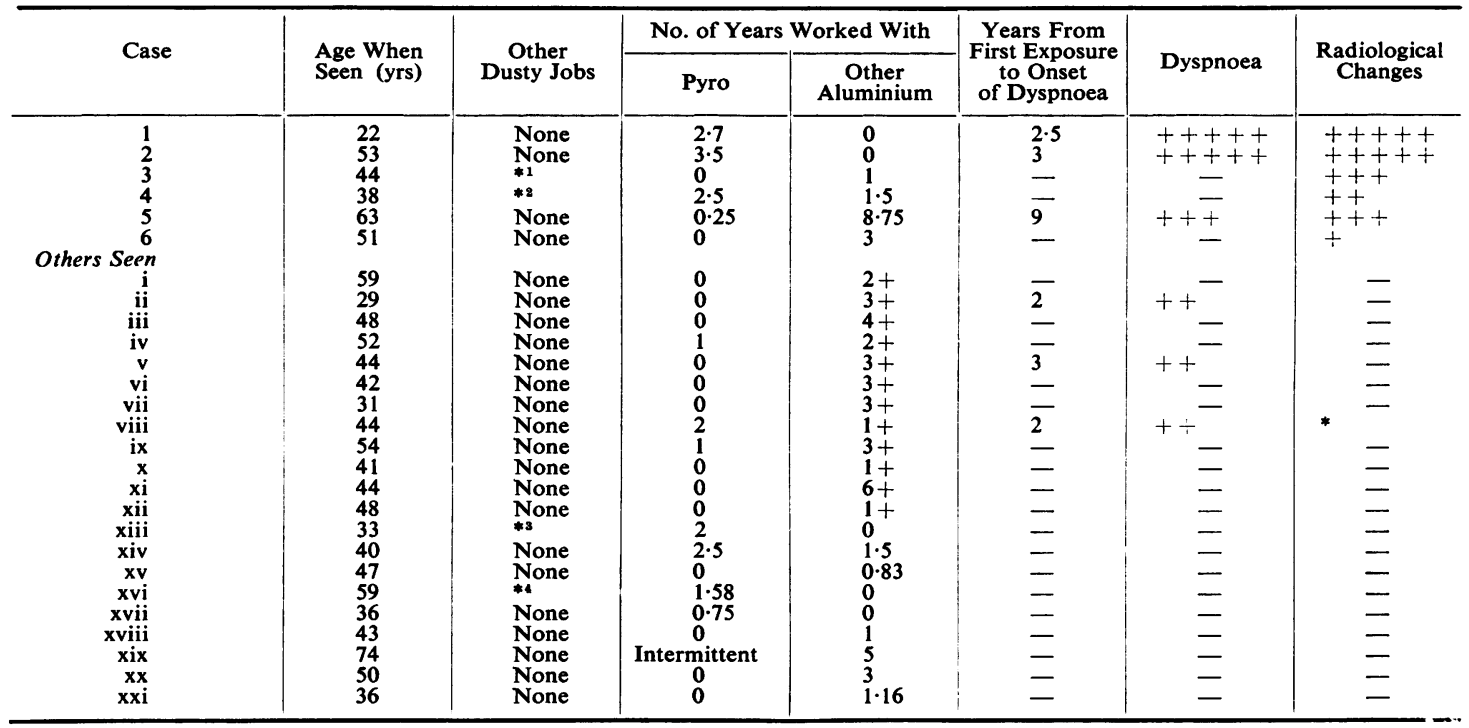

*1 Cotton nine years; ${ }^{* 2}$ coal-mine three months; ${ }^{* 3}$ cotton eight years; ${ }^{* 4}$ foundry four years; ${ }^{*}$ Appearances of emphysema.

TABLE 4

SAMPLES TAKEN IN PYRO STAMPING ROOM DURING EMPTYING AND REFILLING OF MACHINES

\begin{tabular}{|c|c|c|c|c|}
\hline Workman & & No. of Observations & Mean & Standard Deviation \\
\hline $\mathbf{A}$ & $\begin{array}{l}\text { Total dust } \\
\text { Respirable dust } \\
\text { Respirable dust as } \% \text { of total }\end{array}$ & $\begin{array}{l}5 \\
5 \\
5\end{array}$ & $\begin{array}{l}615 \mathrm{mg} . / \mathrm{cu} . \mathrm{m} . \\
51 \mathrm{mg} . / \mathrm{cu} . \mathrm{m} . \\
8 \%\end{array}$ & $\begin{array}{l}69.2 \mathrm{mg} . / \mathrm{cu} . \mathrm{m} . \\
3.9 \mathrm{mg} . / \mathrm{cu} . \mathrm{m} . \\
1.0 \%\end{array}$ \\
\hline B & $\begin{array}{l}\text { Total dust } \\
\text { Respirable dust } \\
\text { Respirable dust as } \% \text { of total }\end{array}$ & $\begin{array}{l}7 \\
7 \\
7\end{array}$ & $\begin{array}{l}685 \mathrm{mg} . / \mathrm{cu} . \mathrm{m} . \\
52 \mathrm{mg} . / \mathrm{cu} . \mathrm{m} . \\
8 \%\end{array}$ & $\begin{array}{l}378.0 \mathrm{mg} . / \mathrm{cu} . \mathrm{m} . \\
20.3 \mathrm{mg} . / \mathrm{cu} . \mathrm{m} . \\
2.2 \%\end{array}$ \\
\hline
\end{tabular}

TABLE 5

APPROXIMATE ESTIMATE OF THE RESPIRABLE ALUMINIUM IN THE ATMOSPHERE AND THE DURATION OF EXPOSURE

\begin{tabular}{|c|c|c|c|c|}
\hline Place & Process & Workman & Time (min.) & Mean Respirable Dust (mg./cu.m.) \\
\hline Stamping room & Empty and refill machines & $\mathbf{A}$ & 90 & 51 \\
\hline $\begin{array}{l}\text { Stamping room } \\
\text { Screening room } \\
\text { Weighing room }\end{array}$ & $\begin{array}{l}\text { Cleaning } \\
\text { Screening } \\
\text { Prepare charges }\end{array}$ & $\begin{array}{c}\mathbf{A} \\
\mathbf{B} \\
\mathbf{A} \text { and } B \\
\mathbf{A}\end{array}$ & $\begin{array}{l}60 \\
60 \\
30 \\
30 \\
30\end{array}$ & $\begin{array}{r}19 \\
114 \\
95 \\
45 \\
84\end{array}$ \\
\hline
\end{tabular}

and the methods they used. Table 4 summarizes the findings in the pyro stamping room during the emptying and refilling of machines, which was the only time they were attended by a workman.

After the powder was removed from the stamping machine it was screened to ensure that it was sufficiently fine. Eleven samples taken in the screening room showed wide variations (as might be expected) with a mean of $95 \mathrm{mg} . / \mathrm{cu} . \mathrm{m}$. of respirable dust. It was found that the men spent approximately three and a half hours per day on dusty work. Table 5 indicates the time spent by two workmen in the pyro process and the mean concentration of respirable dust to which they were exposed.

Particle size was determined by use of a thermal precipitator. The larger particles appeared as flakes of very irregular shape, and the smaller 
particles in the $1-2 \mu$ range frequently adhered in small clumps. There were occasional particles of transparent material which may have been stearin. An estimation of the size range of the dust indicated that $70 \%$ of the particles were $5 \mu$ or less in diameter. The electron microscope showed that all but a few particles were very irregular and flattened. These gave the diffraction pattern of aluminium. The smallest particles giving this pattern measured $0.05 \mu$. Chemical analysis of the dust showed that the free aluminium represented $81.4 \%$ (seven determinations ranging between $78 \%$ and $87 \%$ ). The stearin $(50 \%$ palmitic and $50 \%$ stearic acid) represented $0.5 \%$. Approximately $17 \%$ was represented by oxides and hydroxides of aluminium. A semi-quantitative spectrographic analysis gave the following approximate values: silicon $0.5 \%$; copper, magnesium, manganese, and iron, approximately $0.1 \%$; beryllium was not detected. The carbon added had an average particle size of $0.029 \mu$ and an ultimate composition of $97.9 \%$ carbon.

\section{Discussion}

The first case of pulmonary fibrosis in an aluminium worker was demonstrated by Baader in 1934 (Doese, 1938). During and after the 1939-45 war many more cases were reported in Germany among men making aluminium powder for ammunition; this experience was summarized by Goralewski (1947) who reported 628 workers from six factories of whom $26 \%$ were judged to be uncomplicated cases of pulmonary aluminosis. Other evidence of the incidence of the disease comes from Koelsch (1960), who has been familiar with the industry since 1909. He summarized the German workmen's compensation experience since 1943, when the disease was first recognized for compensation purposes, by saying that 65 cases had been considered of whom 27 were accepted as cases of aluminium lung. Koelsch (1942) attributed the increased incidence during the war to unsatisfactory ventilation imposed by the blackout rules. The main symptom, according to Baader (1949), was dyspnoea; spontaneous pneumothorax frequently occurred. Goralewski (1950) said the same and also mentioned cough and sputum as important symptoms. Sometimes there were no symptoms and scanty findings on percussion and auscultation though the radiological changes were well marked. These changes began with increase of linear striations succeeded by fine foci which tended to aggregate to form cloudy shadows; later the diaphragm showed peaking and the heart shadow became distorted. The pulmonary alveoli became reduced in size by hyalinization and fibrous thickening of the septa. Death often occurred within two years from the onset of symptoms. It is evident that these German authors regard this as an established specific disease. In Japan, Ueda, Mizoi, Maki, Maeda, and Takada (1958) recorded the case of a patient who died three years after he had terminated three years' employment as an aluminium pulverizer; his death was attributed to aluminium dust. In view of the early reports from Germany, Hunter, Milton, Perry, and Thompson (1944) investigated the health of men engaged on grinding propellers made of duralumin (an alloy consisting of $95 \%$ aluminium, $4.5 \%$ copper, and traces of other metals) with alundum (calcined aluminium oxide 95-97\%) wheels. They found no evidence of any disease in the trachea, bronchi, or lungs of these men. We would comment that in Hunter's investigation practically all the fine respirable dust $\left(0.1 \mathrm{mg}\right.$. per $\mathrm{m}^{3}$ in the general atmosphere and as high as $2.7 \mathrm{mg}$. per $\mathrm{m}^{3}{ }^{3}$ near a polisher) was found to be the alundum abrasive; the aluminium particles were, for the most part, above $7 \mu$ in diameter. Crombie, Blaisdell, and MacPherson (1944) investigated 125 workers employed in the Pittsburgh stamp mills of the Aluminium Company of America. The powder was used in the manufacture of paint and ink; the authors made no mention of stearin. Although the workers there had been exposed to aluminium dust for six to 26 years their health was reported to be better than that of the 3,000 other workers employed in the plants. Chest radiographs of all the men taken each year for three years, showed no abnormalities which could be attributed to the inhalation of dust. Assertions that aluminium dust was harmless have been further supported by the work of Denny, Robson, and Irwin (1937), who exposed eight rabbits to an atmosphere containing freshly ground particulate aluminium powder in a concentration averaging 7,000 particles per ml., 12 hours daily for 14 months. They were unable to produce fibrosis or any other significant pulmonary reaction. Crombie et al. (1944), prompted by this experimental work, reported remarkable results in the prevention of silicosis by exposing workers to aluminium dust over long periods. They claimed to have shown conclusively that their method of administering aluminium powder was entirely harmless. On the other hand King, Harrison, Mohanty, and Yoganathan (1958) showed that large doses of powdered metallic aluminium injected intratracheally caused a nodular pulmonary fibrosis in rats.

Turning now to the danger from aluminium as fume, Shaver and Riddell (1947) described lung changes found in workers engaged in the manufacture of corundum (aluminium oxide) abrasive. 
Bauxite, iron, and coke were fused in an electric furnace at about $2,000^{\circ} \mathrm{C}$. During this operation the men were exposed to dense white fume. The cardinal symptom was progressive breathlessness on exertion. Cough with white frothy sputum was usually present. Some cases had spontaneous pneumothorax. The chest radiographs showed widening of the mediastinal shadow; the diaphragm was raised and its outline irregular. There was always abnormal bilateral granular shadowing in the lung fields especially in the upper halves and towards the hilum; coarse shadowing was seen in the more advanced cases which also showed emphysematous changes. In a later paper, Shaver (1948) mentioned the tracheal displacement which we also noted. The pathology was essentially an interstitial lung fibrosis, non-nodular in type, which may be rapidly progressive and accompanied by severe emphysema.

The experience which we have recorded compares closely with those we have quoted. Of the 12 men exposed to fine aluminium powder, two died and two others were affected, and of 15 who worked exclusively on the coarser powder, two had radiological changes but no symptoms. The high incidence of pulmonary fibrosis, for which no other cause could be found, of characteristic pattern and resembling closely cases reported from Germany and Canada, together with the environmental studies, provides strong evidence that the damage to the lungs was caused by the dust. It was apparent that the fine dust was more dangerous than the coarse. Our findings in this respect are in accord with Goralewski (1947) who stated that it was the fine wartime product that was dangerous, contrasted with the coarser powder made in peacetime.

We have found no evidence to show that stearin has been responsible for the fibrosis. In the two fatal cases examinations of frozen sections of lung excluded lipoid pneumonia. Moreover, the coarse powder contained a large amount of stearin $(4 \%)$ compared with the dangerous pyro powder. Goralewski (1947) said that the aluminium powder used for explosives contained no stearin, in contrast with that made in peacetime, which did contain stearin and which was, in general, innocuous. The probability is that the added stearin actually protects against the damage caused by the aluminium particles. This notion has often been put forward in Germany and we have found no contrary evidence and were very interested to learn that in 1952 in our factory the small amount of stearin added in the manufacture of pyro was halved and the amount made up by adding mineral oil. Case 1 first complained of breathlessness in September, 1953; it is possible that the reduction in the amount of stearin is of great significance. Other substances found in the dust were present in amounts too small to warrant serious consideration as the factor responsible for the fibrosis which we have seen in these cases.

It is concluded that finely divided aluminium was responsible for the lung damage. Acceptance of this conclusion is essential if episodes of the type we have described are to be prevented. We think it probable that the duration of exposure, the size of the particles, the density of the dust, and the presence or absence of stearin as well as individual idiosyncrasy are all concerned in the genesis of this pulmonary fibrosis and that variations of these factors account for the apparently discrepant findings of both experimental and clinical workers in this field.

We are glad of the opportunity to acknowledge the cooperation we have had from the management of the factory and for a grant towards the expenses of the investigation. We acknowledge with gratitude the help of numerous colleagues: Dr. E. D. Gray, Dr. G. B. Locke, and Dr. E. Batley for reporting a "blind trial" of the workmen's chest radiographs with controls; Professor E. J. King for access to reports and translations of literature; Dr. Gordon Knowles for translation of German papers; Mr. S. Roach for advice on dust studies and Dr. Colin Ogilvie for carrying out respiratory function tests on Cases 3, 4, 5, and 6 and for his tables and commentary; Mr. R. A. J. Shelton for spectrographic examination of the aluminium powder and Dr. John Chapman for electron microscopy.

\section{REFERENCES}

Baader, E. W. (1949). Z. Unfallmed. Berufskr., 42, 79 and 95. Cited by Nagelscmidt, G. (1959). Pneumoconiosis Abstracts, for years 1951-1955, 3, 240 .

Crombie, D. W., Blaisdell,'J. L., and MacPherson, G. (1944). Canad. med. Ass. J., $50,318$.

Denny, J. J., Robson, W. D., and Irwin, D. A. (1937). Ibid., 37, 1. Doese, M. (1938). Arch. gewerbepath. Gewerbehyg., 8, 501.

Goralewski, G. (1947). Z. Ges. inn. Med., 2, 665. Cited in Excerpta Medica (1949), Sect. VI, 3, p. 304, Abstr. No. 1423.

(1950). Die Aluminiumlunge; Arbeitsmedizin, No. 26. Barth, Leipzig.

Hunter, D., Milton, R., Perry, K. M. A., and Thompson, D. R. (1944). Brit. J. industr. Med., 1, 159.

King, E. J., Harrison, C. V., Mohanty, G. P., and Yoganathan, M. (1958). J. Path. Bact., 75, 429.

Koelsch, F. (1942). Beitr. Klin. Tuberk., 97, 688. Cited by Hunter et al. (1944).

Mitchell (1960). Private communication

Mitchell, J. (1959). Brit. J. industr. Med., 16, 123

Shaver, C. G., and Riddell, A. R. (1947). J. industr. Hyg., 29, 145.

Ueda, M., Mizoi, Y., Maki, Z., Maeda, R., and Takada, R. (1958).

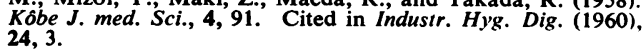

Wright, B. M. (1954). Brit. J. industr. Med., 11, 284. 